\title{
PENGARUH KETERSEDIAAN KOLEKSI BUKU PENUNJANG BAGI KEBUTUHAN BELAJAR SISWA: STUDIKASUS DI PERPUSTAKAAN SEKOLAH DASAR NEGERI LARANGAN TOKOL 1 KECAMATAN TLANAKAN PAMEKASAN MADURA
}

\author{
Yanuastrid Shintawati \\ Universitas Wijaya Kusuma Surabaya \\ Email : yanuastrid@uwks.ac.id
}

\begin{abstract}
ABSTRAK
Dunia pendidikan dasar di era globalisasi sekarang ini siswa pada tingkat sekolah dasar memperoleh banyak informasi baik secara formal dari guru sebagai pengajar, teman, maupun dari masyarakat di lingkungan sekolah juga secara informal melalui kemajuan teknologi semisal radio, televisi dan internet. Untuk memenuhi kebutuhan informasi bagi siswa, guru dan karayawan sekolah harus menyediakan perpustakaan Perpustakaan sekolah memiliki komponen komponen penting yang harus dimiliki salah satu komponen yang sangat penting dalam perpustakaan sekolah adalah ketersediaan koleksi. Ketersediaan koleksi meliputi hal dalam kesiapan bahan pustaka, pemanfaatan dan pendayagunaan koleksi perpustakaan oleh pemustaka. Penelitian ini bertujuan mengetahui ketersediaan koleksi bagi kebutuhan informasi pemustaka yang meliputi kelengkapan, kemutakhiran dan rasio perbandingan jumlah koleksi dengan jumlah siswa dengan mengambil lokasi penelitian di Perpustakaan Sekolah Dasar Negeri Larangan Tokol 1 Kabupaten Pamekasan Madura. Metode penelitian yang digunakan adalah metode kualitatif dekriptif. Hasil penelitian menggambarkan bahwa kelengkapan, kemutakhiran dan rasio ketersediaan koleksi buku penunjang di Perpustakaan Sekolah Dasar Negeri Larangan Tokol 1 Kabupaten Pamekasan Madura reratanya adalah baik sehingga menimbulkan pengaruh yang baik pada peningkatan prestasi siswa siswi Sekolah Dasar Negeri Larangan Tokol 1 Kabupaten Pamekasan Madura.
\end{abstract}

Kata Kunci : Ketersediaan Koleksi, Perpustakaan Sekolah.

\section{PENDAHULUAN}

Dunia pendidikan dasar di era globalisasi sekarang ini siswa pada tingkat sekolah dasar memperoleh banyak informasi baik secara formal dari guru sebagai pengajar, teman, maupun dari masyarakat di lingkungan sekolah juga secara informal melalui kemajuan teknologi semisal radio, televisi dan internet. Secara formal guru dan sekolah sebagai pendidik dan wadahnya menerapkan sistem pembelajaran sekolah dengan mengikuti perkembangan ilmu pengetahuan dan teknologi yang berjalan sesuai dinamika kehidupan sedangkanbagi siswa diharuskan mampu mengikuti sistem tersebut. Dalam kesehariannya siswa memenuhi kebutuhannya untuk mempelajari pengetahuan maupun informasi, juga membutuhkannya untuk meningkatkan nilai pelajaran mereka sehingga sekolah harus menyelenggarakan 
perpustakaan sekolah yang mampu menyediakan bahan informasi yang dibutuhkan oleh siswa siswa tersebut seperti dijelaskan Suwarno (2010:34) bahwa :

“ Perpustakaan sebagai sarana pusat sumber informasi menjadi tulang punggung gerak majunya suatu institusi, terutama institusi pendidikan, tempat tuntutan untuk adaptasi terhadap perkembangan informasi sangat tinggi. Hal ini dikarenakan pemustaka dominan dari kalangan akademisi yang kebutuhannya akan informasi begitu kuat sehingga mau tidak mau perpustakaan harus pula berpikir untuk berupaya mengembangkan diri guna memenuhi kebutuhan pemustaka"

Disamping itu, perpustakaan merupakan salah satu infrastruktur pendidikanyang sangat penting dalam keseluruhan pusat sumber belajar. Dalam lembaga pendidikan sekolah, perpustakaan merupakan salah satu sarana pendidikan yang berfungsi sebagai pusat penyebaran informasi.Menurut Darmono (2010: 1),

"Perpustakaan sekolah sebagai salah satu sarana pendidikan penunjang kegiatan belajar siswa memegang peranan yang sangat penting dalam memacu tercapainya tujuan pendidikan. Penjelasan dalam Undang-undang Nomor 20 Tahun 2003, Sistem Pendidikan Nasional (SISDIKNAS) dalam Sutarno NS (2006:47)," Perpustakaan merupakan sarana penunjang proses belajar mengajar di sekolah"
Dari ungkapan tersebut jelas bahwa perpustakaan sekolah merupakan salah satu bagian yang sangat penting dalam menunjang tercapainya tujuan pendidikan sekolah sehingga keberadaannya sebagai salah satu komponen pendidikan merupakan suatu keharusan.

Perpustakaan memiliki komponen komponen penting yang harus dimiliki salah satu komponen yang sangat penting dalam sebuah perpustakaan adalah ketersediaan koleksi. Ketersediaan koleksi meliputi hal dalam kesiapan bahan pustaka, pemanfaatan dan pendayagunaan koleksi perpustakaan oleh pemustaka. Koleksi perpustakaan merupakan modal utama bagi perpustakaan dan menjadi daya tarik bagi pemustaka untuk berkunjung keperpustakaan, karena informasi yang dibutuhkan pemustaka terdapat pada koleksi yang dimiliki perpustakaan. Sutarno (2006:100) mengatakan bahwa :

" Koleksi atau sumber informasi perpustakaan merupakan salah satu pilar atau kekuatan dan daya tarik utama bagi pengunjung. Oleh sebab itu agar pilar tersebut kuat, maka koleksi perpustakaan juga harus kuat dalam pengertian memadai dalam hal jumlah, jenis ragam dan mutu"

Koleksi yang tersedia di perpustakaan tidak hanya tergantung kepada banyaknya jumlah dan keragaman jenis koleksi yang 
dimiliki namun juga harus ditinjau dari kebutuhan pemakainya dan kemutakhirannya. Sutarno (2006:109) mengatakan bahwa :

\section{" koleksi bahan pustaka yang memadai baik mengenai jumlah, jenis, dan mutunya yang tersusun rapi dengan sistem pengolahan serta kemudahan akses atau temu kembali informasi merupakan salah satu kunci keberhasilan perpustakaan."}

Oleh karena itu, koleksi sebagai sumber informasi harus menjadi program utama untuk selalu dikembangkan. Koleksi perpustakaan hendaknya juga selalu baru dan dapat mengikuti perkembangan ilmu pengetahuan dan teknologi. Pengadaan koleksi perpustakaan sangat tergantung pada pemustaka dan pustakawan, karena keinginan dan permintaan pemustaka terhadap koleksi perpustakaan dikomunikasikan kepada pustakawan.

Perpustakaan sekolah dapat dikatakan berhasil apabila dimanfaatkan oleh pengguna serta memiliki ketersediaan koleksi yang relevan dengan kebutuhan pengguna. Semakin banyak koleksi yang dimiliki perpustakaan diharapkan dapat memenuhi kebutuhan pengguna akan informasi dan pengetahuan. Koleksi yang relevan dengan kurikulum sekolah dapat bermanfaat dalam pengembangan ilmu pengetahuan. Kurikulum yang berlaku disekolah mengharuskan siswa dan guru memakai beberapa buku pelajaran sebagai panduan tidak hanya buku teks pelajaran tapi juga buku penunjang buku teks. Sehingga siswa dan guru membutuhkan banyak koleksi yang menunjang proses belajar mengajar, maka perpustakaan harus dapat memenuhi kebutuhan siswa dan guru tersebut dengan menyediakan koleksi bervariasi. Koleksi - koleksi tersebut harus sesuai dan relevan dengan kebutuhan pengguna agar proses pembelajaran berjalan baik dan dapat dituntaskan dengan hasil yang maksimal.

Kesesuaian antara ketersediaan koleksi pada perpustakaan dengan informasi apa yang dibutuhkan pengguna sangat penting adanya agar proses temu kembali informasi berjalan dengan baik karena adanya kerelevansian koleksi dengan kebutuhan informasi pengguna. Relevansi dapat dijadikan kriteria keberhasilan suatu temu balik informasi yan terdapat pada perpustakaan. Relevansi adalah suatu ukuran keefektivitasan anatara sumber informasi dengan penerima informasi. Dokumen dinilai relevan bila dokumen tersebut memiliki topic yang sama, atau berhubungan dengan subjek yang diteliti ( topical relevance).

Intensitas kunjungan merupakan faktor penentu keberhasilan perpustakaan. Seperti halnya yang kita ketahui bahwa perpustakaan yang berhasil adalah 
perpustakaan yang dikunjungi oleh pemustaka. Jadi agar dapat dimanfaatkan dan dikunjungi dengan baik, perpustakaan haruslah menyediakan koleksi yang memadai dan dan tidak ketinggalan zaman, fasilitas yang lengkap dan layanan yang baik. Berdasarkan uraian diatas peneliti ingin mengetahui seberapa tinggi pengaruh relevansi ketersediaan koleksi dengan pemenuhan kebutuhan informasi siswa di Perpustakaan Sekolah Dasar Negeri Panglegur 2 Kecamatan Tlanakan Pamekasan Madura.

\subsection{IDENTIFIKASI MASALAH}

Untuk merumuskan masalah yang akan dikaji, penulis melakukan identifikasi masalah adalah sbb :

1. Bagaimana kelengkapan koleksi buku penunjang ?

2. Bagaimana kondisi kemutakhiran koleksi buku penunjang ?

3. Sesuaikah jumlah koleksi buku penunjang dengan jumlah siswa?

\subsection{RUMUSAN MASALAH}

Dari latar belakang masalah di atas maka permasalahan yang akan dibahas adalah Bagaimana pengaruh ketersediaan koleksi perpustakaan terhadap kebutuhan belajar bagisiswa : Studi kasus di SD Negeri Larangan Tokol 1 Kecamatan Tlanakan Pamekasan Madura?

\subsection{TUJUAN PENELITIAN.}

1. Untuk mengetahui kelengkapan koleksi dalam memenuhi kebutuhan belajar siswa.

2. Untuk mengetahui kemutakhiran koleksi terhadap relevansi koleksi.

3. Untuk mengetahui kesesuaian jumlah koleksi buku penunjang dengan jumlah siswa.

\section{PEMBAHASAN}

\section{1 LANDASAN TEORI}

\section{Ketersediaan koleksi.}

Ketersediaan berasal dari kata sedia yang artinya siap atau kesiapan. "Ketersediaan adalah kesiapan suatu alat, tenaga, barang, modal, dan siap untuk digunakan atau dioperasikan dalam waktu yang telah ditentukan." (Kamus Besar Bahasa Indonesia,2007:223). Sedangkan menurut Yulia (2009:3) "koleksi perpustakaan adalah kumpulan bahan pustaka yang terdapat di perpustakaan. Untuk dapat memberikan pelayanan yang maksimal perpustakaan harus dapat menyediakan dan mengumpulkan informasi yang sesuai dengan kebutuhan pengguna. Serta keberadaan koleksi harus dibina, dirawat, diatur secara tepat sehingga memudahkan pengguna perpustakaan dalam mencari bahan pustaka. Jumlah koleksi harus selalu

Program Studi Perpustakaan dan Sains Informasi Universitas Wijaya Kusuma Surabaya 
dikembangkan sesuai dengan

perkembangan ilmu pengetahuan.Serta ketersediaan koleksi perpustakaan adalah kesiapan bahan pustaka pada suatu perpustakaan untuk digunakan, dimanfaatkan, dan didayagunakan pengguna perpustakaan. Ketersediaan koleksi perpustakaan sangat menunjang fungsi dan tujuan perpustakaan. Dengan koleksi yang memadai perpustakaan dapat melakukan tugasnya dengan baik.

\section{Tujuan dan Fungsi Ketersediaan} Koleksi.

Menurut Siregar dalam Julianti (2010:6) tujuan penyediaan koleksi adalah untuk memenuhi kebutuhan pengguna akan informasi. Tujuan penyediaan koleksi tidak sama untuk semua jenis perpustakaan, tergantung kepada jenis dan tujuan perpustakaan tersebut. Sebagai contoh perpustakaan sekolah menyediakan koleksi dengan tujuan :

a. Mengumpulkan dan menyediakan bahan pustaka yang dibutuhkan siswa.

b. Mengumpulkan dan menyediakan bahan pustaka sesuai dengan kurikulum sekolah.

c. Memiliki koleksi bahan/dokumen yang lampau dan mutakhir yang sesuai dengan kebutuhan pengguna perpustakaan sekolah. d. Memiliki koleksi yang dapat menunjang pendidikan dan penelitian siswa dan guru.

Dari penjelasan diatas dapat disimpulkan bahwa tujuan perpustakaan dalam menyediakan koleksi harus sesuai dengan kebutuhan informasi penggunanya yaitu siswa dan guru.

\section{Jenis Koleksi Perpustakaan.}

Salah satu unsur utama dalam mendirikan suatu perpustakaan adalah tersedianya koleksi perpustakaan dan mewujudkan fungsi perpustakaan dengan baik. Koleksi perpustakaan terdiri dari bahan tercetak dan terekam. Perpustakaan menyediakan koleksi yang disesuaikan dengan tujuan dan kebutuhan pengguna perpustakaan. Menurut Sutarno ( 2006:54 ) secra umum koleksi yang dimiliki oleh perpustakaan ada dua bagian utama yaitu :

1. Bahan pustaka tercetak, yang termasuk dalam kelompok ini buku teks, surat kabar, majalah, bulletin, pamphlet, kamus, ensiklopedia, direktori, alamanak, indeks, bibliografi, buku tahunan, buku pedoman, dan lain-lain.

2. Bahan pustaka yang terekam yang dalam kelompok ini adalah slide, kaset audio, kaset video, film, strip, CD, VCD, dan lain-lain.

Koleksi perpustakaan merupakan bahanbahan bacaan yang bersifat rekreatif (

Program Studi Perpustakaan dan Sains Informasi Universitas Wijaya Kusuma Surabaya 
mengandung unsur hiburan ) yang memiliki porsi relatif tinggi bahan bacaan yang diminati serta didukung dengan adanya koleksi yang bersifat pendidikan untuk mendukung proses belajar mengajar. Adapun komponen koleksi perpustakaan sekolah dan prosentasenya (Sinaga, 2011:47) :

a. Buku-buku teks $10 \%$

b. Alat peraga $5 \%$

c. Buku-buku referens $15 \%$

d. Buku-buku tentang perpustakaan $1 \%$

e. Bacaan sehat ( fiksi dan keterampilan ) $50 \%$

f. Bacaan tentang daerahnya $4 \%$

g. Buku -buku profesi untuk guru $10 \%$

h. Buku-buku untuk anak luar biasa 5\%

\section{Pengembangan Koleksi.}

Dalam pengadaan koleksi bahan pustaka perlu meninjau kesesuaian koleksi yaitu, menyesuaikan koleksi bahan pustaka dengan pengguna informasi melalui prinsip pemilihan koleksi perpustakaan. Dalam prinsip pembinaan koleksi pada prinsipnya bahan pustaka atau koleksi perpustakaan dapat diperoleh dari pembelian, tukar-menukar, hadiah, droping dari Departemen Pendidikan Nasional, atau buatan sendiri. Adapun beberapa pendapat dari para ahli mengenai prinsipprinsip pemilihan atau seleksi pengadaan koleksi perpustakaan sekolah sebagai berikut :

Prinsip pemilihan koleksi diperpustakaan sekolah menurut Yusuf (2010:26) sebagai berikut :

a. Pemilihan koleksi perpustakaan sekolah disesuaikan dengan kebutuhan kurikulum yang berlaku disekolah.

b. Pemilihan koleksi perpustakaan sekolah disesuaikan dengan kebutuhan kurikulum secara nasional.

c. Pemilihan koleksi perpustakaan sekolah disesuaikan dengan daerah tempat perpustakaan sekolah tersebut berada.

d. Pemilihan koleksi perpustakaan sekolah disesuaikan dengan tingkat kemampuan membaca usia sekolah.

e. Pemilihan koleksi perpustakaan sekolah disesuaikan dengan sistem perpustakaan nasional.

f. Pemilihan koleksi perpustakaan sekolah disesuaikan dengan dana yang tersedia.

\section{Perpustakaan sekolah.}

Menurut Sulistyo-Basuki dalam Lasa Hs (2007:19), “ Perpustakaan adalah sebuah ruangan, bagian sebuah gedung, ataupun gedung itu sendiri yang dugunakan untuk menyimpan buku dan terbitan lainnya yang biasanya disimpan menurut tata susunan tertentu untuk digunakan pembaca, bukan untuk dijual ".

Pengertian perpustakaan sekolah menurut Darmono(2010:3) “ Perpustakaan 
sekolah merupakan bagian integral dari program sekolah secara keseluruhan, dimana bersama-sma dengan komponen lainnya turut menentukan keberhasilan proses pendidikan dan pengajaran”. Reitz dalam Hasugian (2009:78) juga menjelaskan "(school Library), a library in public or private elementary or secondary school that serves the information needs of its students and curriculum needs of its teachers and staf, usually managed by a school librarian or media specialist." Sehingga dapat disimpulkan dari pendapat diatas perpustakaan merupakan suatu unit kerja dari suatu badan atau lembaga tertentu yang mengelola bahan pustaka berupa buku atau lainnya. Serta perpustakaan sekolah merupakan bagian integral dalam proses pendidikan dan pengajaran disetiap jenjang mulai dari sekolah dasar sampai sekolah lanjutan baik milik pemerintah (negeri) maupun swasta yang melayani kebutuhan informasi siswanya, kebutuhan kurikulum dari guru dan staf yang dikelola oleh pustakawan sekolah.

\section{Tujuan dan Fungsi Perpustakaan}

Sekolah.

Menurut Pedoman Umum Penyelenggaraan Perpustakaan Sekolah (2006:5) tujuan perpustakaan sekolah adalah " sebagai sumber belajar dan bagian integral dari sekolah bersama - sama dengan sumber belajar lainnya bertujuan mendukung proses kegiatan belajar mengajar demi tercapainya tujuan pendidikan sekolah bersangkutan”. Sedangkan menurut Sutarno (2006:25) “ tujuan perpustakaan adalah agar tercipta masyarakat terdidik, terpelajar, terbiasa membaca dan berbudaya tinggi".Berdasarkan pendapat diatas dapat disimpulkan, bahwa pada dasarnya tujuan perpustakaan sekolah adalah mewujudkan kemandirian para pengguna perpustakaan yang aktif, kreatif dan mandiri dalam penyelenggaraan pendidikan dengan menyediakan sumber-sumber informasi. Serta perpustakaan sekolah sebagai sumber belajar dengan menghimpun sumber ilmu pengetahuan yang berkaitan dengan kurikulum sekolah yang dapat menumbuhkan minat baca siswa, memperluas dan memperkaya pengalaman belajar siswa, sehingga dapat tercipta siswa yang terdidik, terpelajar dan berbudaya.

\section{Relevansi koleksi dengan kebutuhan informasi. \\ Dari pembahasan pada poin diatas} ada kaitan yang sangat erat antara ketersediaan koleksi perpustakaan dengan pemenuhan kebutuhan informasi siswa dalam kegiatan pelayanan perpustakaan, 
hal ini menjadi dasar hubungan antara ketersediaan koleksi dengan kebutuhan informasi siswa siswi. Perpustakaan sebagai pusat sumber informasi diharapkan dapat memenuhi kebutuhan informasi siswa siswi untuk menunjang proses belajar dan mengajar yang sesuai dengan kurikulum serta ilmu pengetahuan yang berkembang. Dan perpustakaan hendaknya mengusahakan agar koleksi perpustakaan relevan dengan fungsi dan tujuan perpustakaan serta tujuan lembaga induknya. Secara umum, arti dari relevansi adalah kecocokan. Relevan adalah bersangkut paut, berguna secara langsung (Kamus Besar Bahasa Indonesia, 2007: 1159). Perpustakaan harus efektif untuk menghimpun dan menyajikan koleksi bahan pustaka untuk dilayankan kepada pengguna sesuai kebutuhannya. jika pengumpulan, pengolahan dan penyajian koleksi bahan pustaka yang tidak sesuai dengan kebutuhan pengguna akan menimbulkan ketidak efisienan dan pemborosan sumber daya manusia (Sutarno, $2006:$ 14).

\subsection{METODE PENELITIAN}

\section{Pendekatan dan jenis penelitian}

Dalam penelitian ini penulis menggunakan pendekatan kualitatif dalam bentuk deskriptif untuk menggambarkan tentang kondisi sebenarnya dari penyediaan koleksi perpustakaan

SD.Negeri 1 Brenta Tinggi kecamatan

Tlanakan Pamekasan Madura.Menurut

Bogman\& Taylor dalam bukunya Lexy J. Moleong (2002:8). bahwa “ Metode kualitatif sebagai prosedur penelitian yang menghasilkan data deskriptif berupa katakata tertulis atau lisan dari orang-orang dan perilaku yang diamati”. Dalam penelitian ini karena peneliti menggunakan penelitian kualitatif maka peneliti merupakan instrumen utama yang menentukan kualitas penelitian dalam menterjemahkan data yang diperoleh melalui wawancara, observasi dan studi kepustakaan atau dokumen. Penelitian kualitatif diarahkan pada kondisi aslinya, bahwa datanya dinyatakan pada kondisi atau keadaan sebagaimana adanya di lapangan dan selanjutnya peneliti menterjemahkan berdasarkan data di lapangan dari hasil wawancara, observasi maupun juga telaah pustaka yang berkaitan dengan masalah penelitian

\section{Lokasi penelitian}

Penelitian dilakukan di SD Negeri Larangan Tokol 1 KecamatanTlanakan Kabupaten Pamekasan Madura.

\section{Penentuan informan}

Informan adalah orang yang dianggap mengetahui dengan baik tentang masalah yang diteliti, sehingga informan 
dapat memberikan data yang diperlukan dalam penelitian baik secara langsung maupun tidaklangsung. Menurut HB. Sutopo (2002: 50) "Dalam penelitian kualitatif posisi sumber data manusia (narasumber) sangat penting perannya sebagai individu yang memiliki informasinya". Bertindak sebagai informan adalah orang yang dipandang mengetahui permasalahan yang akan dikaji peneliti, serta bersedia memberi informasi kepada peneliti. Informan dari SD Negeri Larangan Tokol 1 kecamatan Tlanakan Pamekasan Maduraadalah dari jajaran stakeholder SD Negeri Larangan Tokol 1 kecamatan Tlanakan Pamekasan Madura dalam hal ini adalah Kepala Sekolah, pustawawan dan beberapa orang siswa SD Negeri Larangan Tokol 1 kecamatan Tlanakan Pamekasan Madura, alasan dari pemilihan dan penentuan informaninforman tersebut di atas adalah informan tersebut terlibat langsung dalam pemanfaatan dan pengelolaan perpustakaan SD Negeri Larangan Tokol 1 kecamatan Tlanakan Pamekasan Madura.

\subsection{HASIL PENELITIAN DAN PEMBAHASAN}

Gambaran umum Sekolah Dasar Negeri

\section{Larangan Tokol 1}

Profil sekolah dan perpustakaanSekolah Dasar Negeri Larangan Tokol 1

\section{Kecamatan Tlanakan Kabupaten Pamekasan}

Sekolah Dasar Negeri Larangan Tokol 1 Pamekasan merupakan sekolah dasar yang berada di Desa Larangan Tokol kecamatan Tlanakan kabupaten Pamekasan. Keberadaan Sekolah Dasar Negeri Larangan Tokol 1 Pamekasan sangatlah strategis mengingat kebutuhan pendidikan sangat dbutuhkan, dan letak dari sekolah sangatlah mudah karena berada di pinggir jalan besar.

Visi dan Misi sekolah Sekolah Dasar Negeri Larangan Tokol 1 pamekasan adalah :Visi" Terwujudnya siswa yang bermutu, berprestasi berdasarkan IMTAQ dan IMTEK", MisiUntuk mewujudkan Visi Sekolah Dasar Negeri Larangan Tokol 1 memiliki misi sebagai berikut :

1. Menimbulkan kebiasaan berperilaku disiplin

2. Melaksanakan pakem sesuai dengan kurikulum

3. Melaksanakan kegiatan ekstra kurikuler

4. Melaksanakan kegiatan berperilaku sopan

5. Melaksanakan kegiatan keagamaan

Keberadaan siswa di sekolah suatu kewajiban selama enam hari dalam seminggu yaitu dari hari Senin sampai dengan Sabtu mereka harus berada di lingkungan sekolah untuk proses belajar dalam menambah wawasan pengetahuan.

Program Studi Perpustakaan dan Sains Informasi Universitas Wijaya Kusuma Surabaya 
Begitu halnya juga dengan siswa di Sekolah Dasar Negeri Larangan Tokol 1, mereka berkewajiban untuk belajar selama enam hari dari hari Senin sampai dengan Sabtu. Sekolah Dasar Negeri Larangan Tokol 1 menerapkan proses belajar dari siswa kelas I sampai dengan kelas VI. Berikut jumlah siswa kelas I sampai dengan kelas VI :

Tabel 1

JUMLAH SISWA TAHUN

AJARAN 2015 / 2016

\begin{tabular}{r|c|c|c|c}
\multirow{2}{*}{ NO } & K E & \multicolumn{3}{|c}{ JUMLAH SISWA/MURID } \\
\cline { 3 - 5 } & L A & Laki & Perempuan & Jumlah \\
& S & laki & & \\
\hline 1 & I & 25 & 25 & 50 \\
\hline 2 & II & 16 & 17 & 33 \\
\hline 3 & III & 15 & 13 & 28 \\
\hline 4 & IV & 20 & 20 & 40 \\
\hline 5 & V & 20 & 13 & 33 \\
\hline 6 & VI & 20 & 20 & 40 \\
\hline Jumlah & 116 & 108 & 224
\end{tabular}

Sumber : Data Sekolah Dasar Negeri Larangan

Tokol 1 Pamekasan

Dari tabel di atas menerangkan dalam proses belajar mengajarnya Sekolah Dasar Negeri Larangan Tokol 1 memiliki siswa keseluruhan sebanyak 224 siswa yang terdiri dari kelas 1 sebanyak 50 siswa, kelas dua sebanyak 33 siswa, kelas tiga sebanyak 28 siswa, kelas empat sebanyak 40 siswa kelas lima sebanyak 33 anak dan kelas enam sebanyak 40 siswa.

\section{Perpustakaan Sekolah Dasar Negeri} Larangan Tokol 1 Pamekasan

Perpustakaan sekolah merupakan suatu unit pelaksana teknis yang dijadikan sebagai salah satu sumber belajar ilmu pengetahuan oleh warga sekolah. Seperti yang dinyatakan Sumiyati dkk (2014: 4.1) perpustakaan sekolah dapat diartikan sebagai perpustakaan yang berada pada lembaga pendidikan sekolah, yang merupakan bagian integral dari sekolah yang bersangkutan dan merupakan sumber belajar untuk mendukung tercapainya tujuan pendidikan sekolah yang bersangkutan. Dari beberapa koleksi yang dimilki oleh perpustakaan Sekolah Dasar Negeri Larangan Tokol 1 Pamekasan dapat dibagi beberapa jenis koleksi yaitu Koleksi pelajaran yang memiliki 3.787 eksemplar, koleksi Koleksi Buku Cerita 50 eksemplar, Koleksi Tebitan berseri 150 eksemplar dan Koleksi Referensi 100 eksemplar. jadi koleksi yang dimiliki oleh Sekolah Dasar Negeri Larangan Tokol 1 Pamekasan dapat dikatakan sudah memenuhi Standart Nasional Perpustakaan dilihar dari jenis dan jumlah koleksi.

Program Studi Perpustakaan dan Sains Informasi Universitas Wijaya Kusuma Surabaya 
Kelengkapan Koleksi Buku Penunjang Perpustakaan SD Negeri Larangan Tokol 1 kecamatan Tlanakan Pamekasan

Dari beberapa penjelasan informan informan dapat diambil kesimpulan bahwa kelengkapan koleksi buku penunjang di Perpustakaan SD Negeri Larangan Tokol 1 bisa dikatakan belum cukup baik dalam memenuhi kebutuhan belajar siswa SD Negeri Larangan Tokol 1 karena tidak semua informan berpendapat bahwa koleksi buku penunjang sesuai dengan kurikulum sudah dapat dikatakan lengkap dan sesuai dengan kebutuhan informasi mereka. Dari pendapat yusup(2010:18-19) menyatakan bahwa khusus informasi yang terdapat kurikulum sekolah yaitu yang bisa mendukung tujuan dan program-program sekolah secara keseluruhan. Sgala macam informasi yang sanggup mendukung program-program sekolah itu dikelola oleh sebuah lembaga atau unit kerja di lingkugan sekolah, yang bersangkutan untuk kemudian dilayankan atau disebarluaskan kepada segenap anggota sekolah seperti siswa, guru, karyawan sekolah, dan juga termasuk didalamnya masyarakat sekita sekolah.Perpustakaan Sekolah memiliki koleksi materi tercetak, multimedia dan digital, sekurang kurangnya 1500 judul meliputi $60 \%$ koleksi nonfiksi sebagai pengayaan ajaran yang terkait dengan kurikulum serta $40 \%$ fiksi yang relevan. Pada akhirnya koleksi perpustakaan hendaknya lengkap dalam arti terkait dengan kebutuhan pemustaka walaupun secara hakiki tidak mungkin sebuah perpustakaan dapat memenuhi semua kebutuhan pemustakanya.

\section{Kemutakhiran Koleksi Buku Penunjang}

Hasil wawancara terkait dengan kemutakhiran koleksi buku penunjang yang dimiliki oleh SD Negeri Larangan Tokol 1 sudah dilakukan dengan upaya dari Kepala Sekolah yang melakukan pengadaan dan pembelian bahan pustaka, hal ini sejalan dengan teori bahwa koleksi hendaknya mengikuti perkembangan ilmu pengetahuan dan teknologi mutakhir, dengan demikian perpustakaan harus mengadakan dan memperbarui bahan pustaka yang menjadi koleksi, hal ini sesuai dengan pernyataan Soeatminah bahwa koleksi yang diadakan oleh suatu perpustakaan hendaknya relevan dengan minat dan kebutuhan, lengkap dan terbitan mutakhir, agat tidak mengecewakan pemustaka yang dilayani (1992: 71).

\section{Rasio ketersediaan koleksi}

dibandingkan dengan jumlah pemakai

Berdasarkan hasil wawancara di atas, penulis menyimpulkan bahwa ketersediaan koleksi perpustakaan sangat menunjang kebutuhan informasi

Program Studi Perpustakaan dan Sains Informasi Universitas Wijaya Kusuma Surabaya 
dan juga mampu meningkatkan prestasi siswa, hal ini tidak lepas dari fungsi perpustakaan yang tidak hanya sekedar penyedia informasi namun juga sebagai wadah edukasi yaitu pengetahuan, pemahaman dan pengajaran. Dengan adanya ketersediaan koleksi yang baik maka perpustakaan dapat berfungsi dengan baik, hal ini sesuai dengan teori bahwa fungsi perpustakaan sekolah yang titik beratnya pada fungsi edukatif dan rekreatif yang sanggu menampung segala macam informasi bersifat edukatif dan rekreatif. Jenis koleksi yang perlu dimiliki oleh perpustakaan sekolah juga harus sejalan dengan fungsi perpustakaan sekolah yang bersangkutan, yakni bersifat edukatif dan rekreatif (Yusup, 2010 : 19). Pengembangan koleksi harus ditujukan kepada pemenuhan kebutuhan pemustaka. Pustakawan dan jajaran pendidik harus bisa membaca kebutuhan informasi pemustaka yang beragam.

\section{KESIMPULAN DAN SARAN}

\subsection{Kesimpulan}

Berdasarkan hasil penelitian yang dilakukan penulis tentang Pengaruh Ketersediaan Koleksi Buku Penunjang di Perpustakaan SD Negeri Larangan Tokol 1 kecamatan Tlanakan Pamekasan , maka penulis mengemukakan beberapa kesimpulan sebagai berikut:

1. Kelengkapan koleksi buku penunjang di Perpustakaan SD Negeri Larangan Tokol 1 kecamatan Tlanakan Pamekasan sudah cukup baik namun masih perlu ditingkatkan

2. Kemutakhiran koleksi buku penunjang dari analisa dan hasil wawancara peneliti sudah baik, terbukti dari upaya sekolah untuk mencari dan mengadakan buku buku dengan edisi terbaru.

3. Rasio ketersediaan koleksi buku penunjang dengan jumlah siswa SD Negeri Larangan Tokol 1 bisa dikatakan baik malah berlebih karena perbandingan jumlah buku lebih banyak dengan jumlah siswa.

4. Dari hasil kelengkapan, kemutakhiran dan rasio ketersediaan koleksi buku penunjang di Perpustakaan SD Negeri Larangan Tokol 1 yang reratanya adalah baik sehingga menimbulkan pengaruh yang baik pada peningkatan prestasi siswa siswi SD Negeri Larangan Tokol 1.

\subsection{Saran}

Berdasarkan hasil penelitian dan analisis yang telah dilakukan, maka penulis memberikan beberapa saran 
sebagai berikut:

1. Sebaiknya sekolah memfokuskan penambahan koleksi pada segi tema atau topik karena yang dikeluhkan dari pustakawan dan siswa adalah ragam koleksi yang belum begitu banyak dan mampu menarik perhatian siswa untuk berkunjung ke perpustakaan.

2. Sekolah utamanya perpustakaan bisa mempertahankan upaya dalam menjaga kemutakhiran koleksinya baik untuk buku penunjang maupun buku buku fiksi.

3. Perlu diadakan sosialisasi koleksi, dengan kerjasama pustakawan, guru dan kepala sekolah untuk lebih kreatif memperkenalkan koleksi di perpustakaan, bisa dengan mengadakan lomba membaca, menulis, dll.

\section{Daftar pustaka}

Alwi, Hasan.(2007). Kamus besar Bahasa Indonesia. Jakarta : Balai Pustaka.

Darmono.(2010). Perpustakaan Sekolah : Pendekatan aspek manajemen dan tata kerja.Jakarta : Gramedia Widiasarana Indonesia.

Hasugian, Jonner (2009). Dasar dasar ilmu perpustakaan dan informasi. Medan : USU Press.

Indonesia Republik. (2006). Pedoman umum pengelolaan koleksi perpustakaan sekolah dan perguruan tinggi. Jakarta : Badan Standar Nasional Pendidikan.
Indonesia Republik. (2006). Sistem pendidikan sekolah dasar dan menengah. Jakarta : Badan Standar Nasional Pendidikan.

Indonesia. (2007). Undang Undang Republik Indonesia Nomor 43 Tahun 2007 Tentang Perpustakaan. Jakarta : Perpustakaan Nasional RI.

Lasa HS. (2005). Manajemen Perpustakaan Sekolah.Yogyakarta :Gama Media

Moleong. Lexy J. (2012). Metodologi penelitian kualitatif. Bandung : Remaja Rosdakarya.

M. Yusuf, Pawit dan Yaya Suhendar.(2010). Pedoman Penyelenggaraan Perpustakaan Sekolah. Jakarta : Kencana.

Rohiat.(2010). Manajemen Sekolah Teori Dasar dan Praktik. Bandung: PT.Refika Aditama.

Sinaga, Dian. (2011). Mengelola perpustakaan sekolah. Bandung : Bedana.

Soeatminah. (1992). Perpustakaan, Kepustakawanan, dan Pustakawan. Yogyakarta : Kanisius.

Sugiyono.(2011). Metode Penelitian Kuantitatif, kualitatif dan R \& D. Bandung: Alfabeta.

Sulistyo Basuki.(2009). Pengantar Ilmu Perpustakaan. Jakarta : Universitas Terbuka.

Sumiati, Opong dkk. (2011). Pengelolaan Perpustakaan Sekolah. Jakarta : Universitas Terbuka

Sutarno NS.(2006). Manajemen 
Perpustakaan : Suatu pendekatan praktek. Jakarta: Samitra Media Utama.

Suwarno, Wiji.(2010). Pengetahuan Dasar Perpustakaan. Bogor: Ghalia Indonesia.

Yulia, Yuyu dan Janti G, Sujana.(2009).

Pengembangan Koleksi. Jakarta:

Universitas Indonesia. 